risk of cardiac arrest. There is an added advantage since cement extruding through these holes acts as a key preventing rotational strains from loosening the cement in the shaft.

I had hoped to study the long-term results by $x$-ray films using radio-opaque cement but, unfortunately, there was some reluctance to use this substance in case of toxic effects.-I am, etc.,

ERIC S. GLen.

Victoria Infirmary,
Glasgow.

SIR,-I was interested to read the medical memorandum on two cases of cardiac arrest associated with bone cement, by Dr. J. N. Powell and others (8 August, p. 326). They state that "A fall in blood pressure in association with the use of bone cement is known to occur, but is rare in the elective operation of total hip replacement, where patients are often younger and fitter." In view of this comment I have reviewed the blood pressure charts of 50 patients undergoing the operation of total hip replacement in this unit and the findings may be of interest.

The majority of patients were aged between 60 and 70 years (22 cases) but there were 13 patients aged between 70 and 80 . two aged over 80 , nine aged between 50 and 60 , and one patient of 46 . Of the charts inspected 26 showed no obvious blood pressure response to insertion of the cement. In 15 cases a definite transient fall occurred, varying from 10 to $30 \mathrm{~mm}$. $\mathrm{Hg}$, but the remaining nine cases are of particular interest.

In these cases the insertion of the cement into the femoral component was followed after approximately one minute by a precipitous fall in blood pressure to $70 \mathrm{~mm}$. Hg. In all cases recovery was rapid, unassisted by transfusion or vasopressors, and normal levels of blood pressure were regained in five to six minutes. The patients' ages ranged from 59 to 84 vears and there was no obvious correlation between age, preoperative condition, or steroid therapy of those who showed this response, and in all cases there had been adequate reolacement of weighed blood loss. The fall and recovery of blood pressure in these cases was so rapid that the original method of recording blood pressure every five minutes missed this fall, and in all cases blood pressure is now measured at minute intervals immediately following insertion of the cement before introduction of the prosthesis.

In vitro experiments reconstituting the C. M. W. Laboratories' cement at room temperature of $23.3^{\circ} \mathrm{C}$. have shown that the maximum temperature of the cement occurs some six minutes after mixing the monomer and the powder - a temperature as high as $96^{\circ} \mathrm{C}$. was recorded. While the cause of this extreme fall in blood pressure in some patients remains obscure it is of interest that the timing of the fall corresponds with the gaining of a very high temperature by the inserted cement, and the recovery of blood pressure with the commencement of the slowing of the chemical process.-I am, etc.,

Phillida M. Frost.

Orthopaedic Unit,

Denbighs.

\section{Epilepsy and Driving}

SIR,-The new regulations relating to the eligibility of certain epileptics to drive would appear to be far from clear (15 August, p. 407). No guidance is given in the regulations as to whether the control of fits should be with or without anticonvulsants. If applicants have their episodes controlled by such medication, how does one overcome the current restriction relating to driving under the influence of drugs, especially as anticonvulsants are soporific in their action?

I should be interested to know what "evidence" the authorities expect to receive in order to confirm that three-year requirement? For almost 20 years I have been actively concerned in the placing of disabled persons (unregistered as well as registered) in suitable employment. It has been my experience that, as a group, epileptics are more prone to withhold detrimental information than other groups. Why then, $\mathrm{Sir}$, as mentioned in your leading article (15 August, p. 362) should "informed medical opinion" feel that this human failing is less likely to be evident when applying for a longed-for driving licence? After all, the applicant's general practitioner has no satisfactory practical way of confirming his patient's statement when requested for a report by the medical officer of health

A history of epilepsy, whether controlled or not, still bars the issue of a Heavy Grade Vehicle or Public Service Vehicle licence. Such drivers are no less likely to run into a bus queue than those of private cars-and there are far more of the latter. On the other hand, consider the epileptic driving a private car who could (due either to drug effects or an actual fit) veer across the road and be involved in a collision with a fully-laden motor coach coming in the opposite direction.

There is already more than enough avoidable carnage on our roads; surely some further thinking is required before it is too late?-I $2 \mathrm{~m}$, etc.

\section{F. J. ROBERTSON.}

Newcastle upon Tyne.

\section{English Language Problems}

SIR,-In reply to Dr. H. Joshi's letter (18 August, p. 348) regarding the English language problems of Commonwealth doctors it is surely an understatement to say that the pronunciation of people in different parts of the country is their only problem. I have taught English to doctors from overseas for eight years and know that the main difficulties are understanding colloquial English in rapid speech, understanding dialectal variations in speech, writing good English, and making themselves understood in their own variation of English. We don't blame them for speaking differently, but many of them must face the fact that they do.

To help my own work ${ }^{1}$ I should be grateful if English doctors would send me a note of any unusual regional expressions heard in the patient-doctor relationship.-I am, etc.,

Joy E. Parkinson.

19B Swain's Lane, London N.6.

1 Parkinson, J. E., A Manual of English for the Orkinson, J. E., A Manual of English for the
Overseas Doctor, Edinburgh, Livingstone, 1969.

\section{Leucocytes in Semen}

SIR,-In the report of the session on subfertility at the Annual Scientific Meeting (18 July, p. 157) it was said that the significance of leucocytes in the semen was not known.

While this is true in many cases, particularly when the numbers are small, it is important to remember that polymorphs in the semen may be the first sign of genitourinary tuberculosis in a man who is being investigated for subfertility. The leucocytes are best seen in slides stained by Papanicolaou's method. In these cases, specimens of urine should be examined and cultured. In addition, at least three specimens of the whole of the early morning urine should be cultured for Mycobacterium tuberculosis. - I am, etc.,

\section{H. C. M. WaLtoN.}

Beck Laboratory,
Swansea Hospital, Swansea.

\section{Malabsorption and Intestinal Flora}

SIR,-A report ${ }^{1}$ last year of a number of cases of tropical sprue patients displaving abnormal flora of the small bowel, coupled in some cases with malabsordtion of fat and vitamin $\mathrm{B}_{12}$, and B.M.F. articles (9 May, p. 340 and 16 May, p. 380) prompt me to report a case of longstanding diarrhoea and malabsorption. This patient's historv supports the premise that an abnormal flora of the small bowel mav be involved.

A male aged 49 has always resided in England. For 10 years he suffered attacks of diarrhoea and abdominal pain. After six years of palliative treatment he complained of extreme lassitude and darkening of the skin. His weight had fallen to under 8 st. $(52 \mathrm{~kg}$.). As many as 10 frothy fatty offensive stools were passed each dav. The blood picture showed a megaloblastic anaemia. Marrow biopsy confirmed iron, $\mathrm{B}_{12}$ and folic acid deficiencies. Electrolvtes were normal: haemoglobin $85 \%$, M.C.H.C. $31 \%$, serum iron $8 \mu \mathrm{g} . \%$, serum $B_{12} 75 \mu \mathrm{g} . / \mathrm{ml}$., serum folate $1.5 \mathrm{mg} . / \mathrm{ml}$. A xvlose excretion test showed that $10 \%$ only of xylose was excreted in the urine in 5 hours. The day faecal fat estimation was $21.8 \mathrm{~g}$./day. The appearance of the small bowel suggested steatorrhoea and a biopsy of the jejunum showed a flat mucosa. A diagnosis of coeliac syndrome was made.

The anaemia responded to and continues to be controlled bv injections of vitamin $\mathbf{B}_{12}$ in conjunction with iron, folic acid, and an oral multiple vitamin preparation. At first a gluten-free diet produced some response with his weight rising to $9 \mathrm{st}$. $2 \mathrm{lb}$. (58 kg.) The diarrhoea persisted and gradually his weight dropped to $8 \frac{1}{3} \mathrm{st}$. ( $55 \mathrm{~kg}$.). Two years later a haemophilus-like organism was cultured from the jejunal juice. Immediate response to tetracycline therapy was good, but after some months was not maintained. His condition deteriorated with sometimes as many as 15 bowel motions a day with abdominal pain and tenderness. Sedatives, alkalis, spasmolytics, and antibiotic therapy were all tried without lasting benefit.

A little over a year ago he was put on Sedacol, a mixture of clioquinol and phanquone, in an attempt to normalize his intestinal flora. Two tablets t.d.s. for two 